\title{
Is crystalloid cardioplegia a strong predictor of intra-operative hemodilution?
}

\author{
Murat Günday ${ }^{1}$ and Hakan Bingöl ${ }^{2 *}$
}

\begin{abstract}
Introduction: Complications due to hemodilution (hematocrit value less than 22\%) after cardiopulmonary bypass inevitably resulted with significantly greater intensive care requirements, long hospital stays, more operative costs, and increased mortality rates. We tried to identify whether crystalloid cardioplegia is the strongest predictor of intraoperative hemodilution or not.

Materials and methods: One hundred patients were included into this randomized prospective study. Patients were divided into the two groups. Crystalloid cardioplegia were given to the odd-numbered patients (Group 1, $\mathrm{n}=50$ patients) and blood cardioplegia were given to the even-numbered patients (Group 2, $\mathrm{n}=50$ patients). St. Thomas-II solution was used in Group-1 and Calafiore cold blood cardioplegia was in Group-2.
\end{abstract}

Results: Average intraoperative hematocrit value was $18.4 \% \pm 2.3$ in crystalloid group $24.2 \% \pm 3.4$ in blood cardioplegia group ( $p<0.001)$. The lowest hematocrit value was $15 \%$ and $20 \%$ in two groups respectively $(p<0.001)$. In crystalloid group average intraoperative packed red blood cell (RBC) transfusion was $2.3 \pm 0.41$ units, $0.7 \pm 0.6$ units blood cardioplegia group $(p=0.001)$. Average transfused RBC was $2.7 \pm 0.8$ units in crystalloid group, $0.9 \pm 0.4$ units blood cardioplegia group ( $p<0.001)$. Multivariate analyses confirmed age $(p=0.005, O R=3.78)$, female gender $(p=0.003, O R=2.91)$, longer cross-clamp time ( $>60$ minutes) $(p=0.001, O D=0.97)$, body surface area $<1.6 \mathrm{~m}^{2}$ $(p=0.001, O R=6.01)$ and crystalloid cardioplegia $(p<0.001, O R=0.19)$ as predictor of intraoperative hemodilution.

Conclusion: Crystalloid cardioplegia, compared to blood cardioplegia not only causes much more intra-operative hemodilution but also increases the blood transfusion requirement. Hemodilution and increased transfusion increases the intensive care unit and hospital stay, in the early postoperative period.

Keywords: Cardioplegia, Crystalloid, Coronary artery, Bypass, Hemodilution

\section{Background}

The effect of hemodilution during cardiopulmonary bypass is extensively studied and lower hematocrit levels $(<22 \%)$ caused postoperative organ failure [1]. Renal failure, stroke, perioperative myocardial infarction, prolonged mechanical ventilation and multiorgan failure are much more common in hemodilution conditions [2]. There are several predictors of hemodilution. Prebypass hematocrit values (such as anemia), female gender, Cardiopulmonary bypass $(\mathrm{CPB})$ time, age, renal failure, and small body surface area (BSA) are the strong predictor of hemodilution and consequently blood transfusion [3-5]. We know that

\footnotetext{
* Correspondence: hbingol@gmail.com

2Department of Cardiovascular Surgery, Ankara Çankaya Hospital, Aşağı Dikmen mah. 575 sok, Orankent konutları B blok No:12, OR-AN Çankaya, Ankara, Turkey

Full list of author information is available at the end of the article
}

allogenic blood transfusion increases the risk of mortality [6] and morbidity such as pulmonary edema [7], renal failure [8], transfusion complications [9]. There are lots of surgeons still using Crystalloid Cardioplegia for its simplicity, economy and fairly good efficacy in the vast majority of patients. Nevertheless, Crystalloid Cardioplegia presents major disadvantages compared with the same volume of blood cardioplegia [10]. It poorly supplies oxygen; it increases the degree of hemodilution which is already high after circulation of the priming volume and it decreases the oncotic pressure [11]. As we mentioned negative effects of hemodilution and blood transfusion are clarified. We have prospectively investigated the effects of Crystalloid Cardioplegia on hemodilution and necessity of blood transfusion by comparing with blood cardioplegia. 


\section{Methods}

Between 2010-2013, One hundred patients were included into our randomized prospective study. We decided to give Crystalloid cardioplegia to the odd-numbered patients and blood cardioplegia to the even numbered patients. Informed consents were obtained from all patients. Institutional board approval from ethical committee of hospital (Süleyman Demirel University, Faculty of Medicine) was also obtained (November 13, 2006/3). Crystalloid cardioplegia (St. Thomas-II solution) have been used in Group-1. Fifteen $\mathrm{ml} / \mathrm{kg}$ St-Thomas II solution was given both antegrade and retrograde initially. Then in every 20 minutes St-Thomas II solution was given retrograde $(7 \mathrm{ml} / \mathrm{kg})$. Just before cross-clamp removal $150 \mathrm{ml}$ St-Thomas II and $250 \mathrm{ml}$ blood were given antegradely (Hot shot). Calafiore blood cardioplegia was used in group- 2 patients $[12,13]$. This solution was given at the $600 \mathrm{ml}$ warm solution and $600 \mathrm{ml}$ cold solution in the induction period then $600 \mathrm{ml}$ cold solution in every 20 minutes both antegradely and retrogradely. Just before cross clamp removal $600 \mathrm{ml}$ warm blood cardiplegia (Hot Shot) with lower potassium ( $4 \mathrm{mmol}$ ) was given antegradely (Table 1$)$. Patients' characteristics were summarized in Table 2.

\section{Operative characteristics}

All patients in both groups had elective operations. All patients underwent primary coronary revascularization. $\mathrm{CPB}$ was done in all patients with two stage venous and aortic cannula. Moderate hypothermia $\left(26^{\circ} \mathrm{C}\right)$ and topical cooling with iced saline slush were used in all patients. Myocardial preservation was accomplished as mentioned previously in both groups. CPB was established with a roller pump, non-pulsatile flow after anticoagulation with bovine lung heparin ( $3 \mathrm{mg} / \mathrm{kg}$ ) and activated clotting time was maintained for more than $480 \mathrm{~s}$. Membrane oxygenators (Capiox-E Terumo Corp, Tokyo, Japan) were used. Heparin was neutralized by protamine $(3.5 \mathrm{mg} / \mathrm{kg})$ at the end of the CPB. All distal anastomoses were done in a single cross-clamp period.

\section{Transfusion protocols}

Packed red blood cell transfusion was used when hematocrit (Htc) levels were less than 22\% during the intraoperative period. Mostly Packed red blood cell (RBC) added pump reservoir during the $\mathrm{CPB}$ period. Transfusion was done when hematocrit $<18 \%$ in the postoperative period. In older patients ( $>70$ years old) Hct levels $<20 \%$ was accept as the lowest limit. Platelet transfusion and fresh frozen plasma was limitedly used in both groups. Fluid regime strictly followed during the postoperative periods.

\section{Sample size}

According to our previous clinical observations, crystalloid cardioplegia reduces intraoperative Htc levels below $25 \%$ in coronary artery bypass graft (CABG) patients. We predicted $10 \%$ reduction of Htc levels in blood cardioplegia patients. To detect this difference with 95\% confidence limits and power of $80 \%$ we needed to enter at least 49 patients into each group [14].

\section{Exclusion criteria}

All re-operative and urgent and emergency procedures, reoperations, bleeding disorders, dialysis dependent renal failure, and anemic patients (preoperative Hct $<20 \%$ ) were excluded.

\section{Statistical analyses}

Statistical analysis was performed with SPSS software version 10.0 (SPSS Inc., Chicago, IL). Clinical data were expressed as mean values \pm standard deviation. Differences were analyzed with Fisher's exact test, $X^{2}$-test, unpaired Student's $t$-test and Mann-Whitney test. We investigated the effects of the variables on hemodilution and transfusion requirement by calculating odds ratios (OR) in univariate analyses for all CABG patients. Variables for which the unadjusted $p$-value was $\leq 0.20$ in logistic regression analysis were identified as potential risk markers and included in the full model. We conducted stepwise multivariate analyses by using logistic regression. We reduced the model by using backward elimination and we eliminated potential risk markers by using likelihood ratio tests.

\section{Results}

Average CPB time was $87 \pm 14$ minutes in crystalloid group, $94 \pm 11$ in blood cardioplegia group $(\mathrm{p}=0.301)$. Average cross clamp time was $61 \pm 15$ and $58 \pm 23$ minutes in both groups respectively ( $\mathrm{p}=0.433$ ). Low cardiac output developed in 11 patients in crystalloid and 5 patients in blood cardioplegia group $(\mathrm{p}=0.044)$. Positive inotropic drugs were used in 17 patients in crystalloid cardioplegia group, 8 patients in blood cardioplegia group $(\mathrm{p}=0.032)$. Intra-aortic balloon was inserted to five patients in crystalloid group and only one patient in blood cardioplegia group. Dialysis required renal failure was developed only one patient in crystalloid cardioplegia group. Four patients

Table 1 Ingredients of calafiore cold blood cardioplegia solution

\begin{tabular}{llr}
\hline INDUCTION & Native blood; $1000 \mathrm{ML}$ Ringer solution; $70 \mathrm{mmol} \mathrm{K}$; $30 \mathrm{ml} \mathrm{8.4 \%} \mathrm{NaHCO}$; ratio "4/1 & $600 \mathrm{ml}$ warm solution; $600 \mathrm{ml}$ cold solution \\
MAINTENANCE & Same additives with induction & $600 \mathrm{ml}$ cold solution \\
HOT SHOT & $4 \mathrm{mmol} \mathrm{K+}$ & $600 \mathrm{ml}$ warm solution \\
\hline
\end{tabular}


Table 2 Preoperative characteristics of patients

\begin{tabular}{|c|c|c|c|}
\hline Variable & Crystalloid cardioplegia $[\mathrm{no}=50]$ & Blood cardioplegia $[\mathrm{no}=50]$ & $p$ value \\
\hline $\mathrm{Age}^{*}$ & $61 \pm 12$ & $63 \pm 9$ & 0.651 \\
\hline Male & 37 & 39 & 0.466 \\
\hline Smoking & 34 & 29 & 0.012 \\
\hline COPD & 12 & 14 & 0.834 \\
\hline Hypertension & 25 & 21 & 0.543 \\
\hline Congestive heart failure (no) & 2 & 3 & 0.335 \\
\hline Peripheral vascular disease & 11 & 9 & 0.746 \\
\hline Cerebral vascular disease & 6 & 7 & 1.00 \\
\hline Average body surface area (BSA m²) & $1.91 \pm 0.5$ & $1.89 \pm 2.2$ & 0.855 \\
\hline Body mass index $\left(\mathrm{kg} / \mathrm{m}^{2}\right)^{*}$ & $33.4 \pm 4.2$ & $29.3 \pm 6.8$ & 0.455 \\
\hline Ejection fraction (\%)* & $45.6 \pm 7.8$ & $50.1 \pm 3.6$ & 0.023 \\
\hline Preoperative IABP & 2 & - & 0.242 \\
\hline Number of diseased vessels* (range 1-4) & $2.1 \pm 0.4$ & $1.9 \pm 0.6$ & 0.744 \\
\hline LMCA disease (>50\%) & 5 & 3 & 0.721 \\
\hline Previous Ml & 31 & 37 & 0.462 \\
\hline Previous PTCA or stent & 8 & 11 & 0.631 \\
\hline Preoperative hematocrit value (\%) & $38.5 \pm 3.7$ & $40.4 \pm 5.6$ & 0.563 \\
\hline Preoperative hemoglobine value ( $\mathrm{gr} / \mathrm{dL})$ & $13.3 \pm 2.3$ & $13.9 \pm 2.9$ & 0.646 \\
\hline
\end{tabular}

*mean \pm SD.

Abbrevations: COPD chronic obstructive pulmonary disease, IABP IABP intra-aortic balloon pump, LMCA left main coronary artery, MI myocardial infarction, PTCA Percutaneous transluminal balloon angioplasty.

required a second look for hemorrhage in crystalloid group and two patients in blood cardioplegia group $(\mathrm{p}=0.677)$. Radial artery was used in 17 patients in group 1 and 19 patients in group 2. LITA was used 45 patients in group 1 and 47 patients in group 2. Average intraoperative hematocrit (\%) value was $18.4 \pm 2.3$ in crystalloid group $24.2 \pm 3.4$ in blood cardioplegia group $(\mathrm{p}<0.001)$. The lowest Htc value was $15 \%$ and $20 \%$ in both groups respectively ( $\mathrm{p}<0.001$ ). $2.3 \pm 0.41$ units packed $\mathrm{RBC}$ transfusion was necessary intra-operatively in crystalloid group, $0.7 \pm 0.6$ units in blood cardioplegia group $(\mathrm{p}=0.001)$. Average transfused $\mathrm{RBC}$ was $2.7 \pm 0.8$ units in crystalloid group, $0.9 \pm 0.4$ units blood cardioplegia group $(\mathrm{p}<0.001)$. Mean intensive care unit (ICU) stay was $2.7 \pm 1.2$ days in crystalloid group, $1.1 \pm 0.45$ days in blood cardioplegia group $(\mathrm{p}=0.001)$. Mean hospital stay was $8.6 \pm 2.1$ versus $6.4 \pm 1.1$ days in respectively $(\mathrm{p}<0.001)$. Two patients died in crystalloid group but none in blood cardioplegia group ( $\mathrm{p}=0.494)$. Perioperative and postoperative variables were summarized in Table 3 .

\section{Predictors of intra-operative hemodilution}

Data for all groups were combined and 11 variables were subjected to statistical analysis as a predictor of intraoperative hemodilution (Htc $<22 \%$ ). As shown in Table 4, univariate analysis identified age $(\mathrm{p}=0.009, \mathrm{OR}=2.07)$, female gender $(\mathrm{p}=0.007$, $\mathrm{OR}=0.89)$, longer cross-clamp time $(>60$ minutes $)(\mathrm{p}=0.046, \mathrm{OD}=0.97), \mathrm{BSA}<1.6 \mathrm{~m}^{2}$ $(\mathrm{p}=0.005, \mathrm{OR}=5.60)$ and crystalloid cardioplegia $(\mathrm{p}<$ 0.001 , $\mathrm{OR}=0.36)$ as predictors of intraoperative hemodilution. The value of $-2 \log$ likelihood of multivariate analyses was 421.504. Multivariate analyses confirmed five of six variables. These were age $(\mathrm{p}=0.005, \mathrm{OR}=$ $3.78)$, female gender $(\mathrm{p}=0.003$, OR $=2.91)$, longer cross-clamp time ( $>60$ minutes $)(p=0.001$, OD $=0.97)$, BSA $<1.6 \mathrm{~m}^{2}(\mathrm{p}=0.001, \mathrm{OR}=6.01)$ and crystalloid cardioplegia $(\mathrm{p}<0.001, \mathrm{OR}=0.19)$.

\section{Predictors of transfusion requirement of packed red blood cells}

Data for all groups were combined and 11 variables were subjected to statistical analysis as a predictor of transfusion requirement of packed red blood cell. As shown in Table 5 univariate analysis identified age $(p=0.034, O R=3.1)$, female gender $(\mathrm{p}=0.004, \mathrm{OR}=1.12), \mathrm{CPB}$ time $(\mathrm{p}=0.006$, $\mathrm{OR}=2.33)$, longer cross-clamp time $(>60$ minutes $)(\mathrm{p}=$ $0.003, \mathrm{OD}=2.16), \mathrm{BSA}<1.6 \mathrm{~m}^{2}(\mathrm{p}=0.001, \mathrm{OR}=3.71)$ and crystalloid cardioplegia $(\mathrm{p}<0.001, \mathrm{OR}=1.25)$ as predictors of transfusion requirement. Multivariate analyses confirmed five of six variables. These were female gender $(p=0.023$, $\mathrm{OR}=3.91)$, CPB time $(\mathrm{p}=0.001, \mathrm{OR}=1.7)$, longer crossclamp time ( $>60$ minutes) $(\mathrm{p}=0.001, \mathrm{OD}=4.45), \mathrm{BSA}<1.6$ $\mathrm{m} 2(\mathrm{p}<0.001, \mathrm{OR}=3.83)$ and crystalloid cardioplegia $(\mathrm{p}<0.001, \mathrm{OR}=0.78)$. 
Table 3 Perioperative and postoperative variables

\begin{tabular}{|c|c|c|c|}
\hline Variable & Crystalloid cardioplegia $[\mathrm{no}=50]$ & Blood cardioplegia $[\mathrm{no}=50]$ & $\mathrm{p}$ value \\
\hline CPB time (min) & $87 \pm 14$ & $94 \pm 11$ & 0.301 \\
\hline Cross-clamp time & $61 \pm 15$ & $58 \pm 23$ & 0.433 \\
\hline Distal anastomosis (range 1-4) & $3.4 \pm 0.9$ & $3.1 \pm 0.4$ & 0.244 \\
\hline Low cardiac output & 11 & 5 & 0.044 \\
\hline IABP & 5 & 1 & 0.031 \\
\hline Positive inotropic drug requirement & 17 & 8 & 0.032 \\
\hline Renal failure need dialysis & 1 & - & 1 \\
\hline \multicolumn{4}{|l|}{ Revision } \\
\hline Tamponade & 1 & 1 & - \\
\hline Bleeding & 3 & 1 & 0.677 \\
\hline Ventilation $>48$ & 2 & 1 & 1.00 \\
\hline Sternal dehissence & 3 & - & 0.242 \\
\hline $\mathrm{TIA}$ & 1 & 1 & - \\
\hline Stroke & 1 & - & - \\
\hline Sternal wound infection & 2 & 1 & - \\
\hline Mediastinitis & 1 & - & - \\
\hline \multicolumn{4}{|l|}{ Internal thoracic artery } \\
\hline -None & 2 & 3 & 1.00 \\
\hline -Single & 45 & 47 & 0.751 \\
\hline -Double & 3 & - & \\
\hline Radial artery & 17 & 19 & 0.835 \\
\hline Saphenous vein & 50 & 50 & 1.00 \\
\hline Average intraoperative Htc (\%) & $18.4 \pm 2.3$ & $24.2 \pm 3.4$ & $<0.001$ \\
\hline Nadir intraoperative Htc (\%) & 15 & 20 & $<0.001$ \\
\hline Average intraoperative $\mathrm{Hb}(\mathrm{gr} / \mathrm{dL})$ & $5.5 \pm 1.2$ & $6.7 \pm 1.3$ & 0.001 \\
\hline Average intraoperative transfusion of Packed RBC & $2.3 \pm 0.41$ & $0.7 \pm 0.6$ & 0.001 \\
\hline Average transfusion of packed RBC & $2.7 \pm 0.8$ & $0.9 \pm 0.4$ & $<0.001$ \\
\hline Average FFP transfusion & $2.1 \pm 0.2$ & $1.2 \pm 0.8$ & 0.001 \\
\hline Average platelet transfusion & $1.2 \pm 0.3$ & - & \\
\hline Mortality & 2 & - & 0.494 \\
\hline ICU stay (days) & $2.7 \pm 1.2$ & $1.1 \pm 0.45$ & 0.001 \\
\hline Hospital stay (days) & $8.6 \pm 2.1$ & $6.4 \pm 1.1$ & $<0.001$ \\
\hline SVT & 29 & 21 & 0.008 \\
\hline
\end{tabular}

Abbrevations: $C P B$ cardiopulmonary bypass, IABP intra-aortic balloon pump, TIA transient ischemic attack, Htc Hematochrit, $H b$ Hemoglobine, $R B C$ Red blood cell, FFP fresh frozen packed, ICU intensive care unit, SVT supraventricular tachycardia.

\section{Discussion}

Cardioplegia protects the heart from ischemic injury and postoperative heart failure during cardiopulmonary arrest period. Initially crystalloid cardioplegia was introduced as an agent to allow for hypothermic hyperkalemic arrest. Various additives were explored to optimize the myocardium during the time of ischemia [15]. Although cardioplegia is generally accepted to be a mandatory tool for myocardial protection during on-pump cardiac surgery, there is still controversy regarding various aspects including its composition, temperature, and mode of delivery.
Blood was then found to be the most logical vehicle for delivery of potassium cardioplegia [16,17] The optimal cardioplegic temperature, timing, and routes of delivery were further explored [18]. There are still controversies between crystalloid and blood cardioplegia for better myocardial protection. Øvrum E. and colleagues [19] did not found statistically significant differences between crystalloid and blood cardioplegia. Rinne T [20] demonstrated a higher incidence of spontaneous resumption of sinus rhythm after blood cardioplegia compared with that after crystalloid cardioplegia. But Øvrum E and colleagues [19] 
Table 4 Effects of various variables on the intraoperative hemodilution $(\mathrm{Htc}<22)$ based on univariate and multivariate logistic regression analyses

\begin{tabular}{|c|c|c|c|c|c|c|}
\hline & & & & & riate & \\
\hline & Unadjusted odds ratio & $95 \% \mathrm{Cl}$ & $\overline{p \text { value }}$ & Adjusted* odds ratio & $95 \% \mathrm{Cl}$ & $p$ value \\
\hline Age & 2.07 & $1.66-3.34$ & 0.009 & 3.78 & $2.67-4.33$ & 0.005 \\
\hline Female & 0.89 & $0.42-1.85$ & 0.007 & 2.91 & $1.99-3.01$ & 0.003 \\
\hline Diabetes & 0.99 & $0.55-1.88$ & 0.712 & 1.66 & $0.2-5.43$ & 0.476 \\
\hline $\mathrm{EF}$ & 0.92 & $0.89-0.96$ & 0.101 & 1.7 & $0.1-7.8$ & 0.765 \\
\hline CPB time & 1.03 & $0.99-1.10$ & 0.211 & 2.6 & $2.1-2.91$ & 0.001 \\
\hline X-clamp time $>60$ & 0.97 & $0.91-1.05$ & 0.046 & 0.97 & $0.94-1.03$ & 0.001 \\
\hline COPD & 3.41 & $2.13-4.29$ & 0.111 & 3.94 & $2.35-6.99$ & 0.178 \\
\hline LITA & 0.49 & $0.25-0.81$ & 0.023 & 0.65 & $0.32-1.25$ & 0.230 \\
\hline Radial artery & 0.75 & $0.36-1.42$ & 0.442 & 2.11 & $1.01-3.36$ & 0.536 \\
\hline $\mathrm{BSA}<1.60 \mathrm{~m}^{2}$ & 5.60 & $4.71-8.95$ & 0.005 & 6.01 & $5.67-6.33$ & 0.001 \\
\hline Crystalloid cardioplegia & 0.36 & $0.19-0.62$ & $<0.001$ & 0.19 & $0.08-0.35$ & $<0.001$ \\
\hline
\end{tabular}

*Adjusted for ejection fraction, cross-clamp time, LITA, COPD.

$E F$ ejection fraction, $C P B$ cross-clamp time, LITA left internal thoracic artery, COPD chronic obstructive pulmonary disease, $B S A$ body surface area.

found no statistical differences concerning conduction disturbances. Blood as opposed to crystalloid cardioplegia could potentially improve postoperative cardiac outcomes, because it more closely approximates normal physiology caused in part by its oxygen carrying capacity and less associated hemodilution [15].

Intraoperative hemodilution and transfusion requirement becomes most critical subjects in the last decade [1-9]. Habib RH [1] specifically showed that major complications, including stroke, myocardial infarction, low cardiac output syndrome, renal failure, pulmonary edema, reoperation due to bleeding, sepsis, and multiorgan failure, were increased as the nadir hematocrit during CPB decreased. Moreover, this hematocrit-complications association inevitably resulted in significantly and systematically greater intensive care requirements, hospital stays, operative costs, and death with increasing levels of hemodilution, particularly for the lowest value less than $22 \%$. Defoe and colleagues [2] found that patients with a lower hematocrit during cardiopulmonary bypass were associated with a higher risk of in-hospital mortality. However they did not provide data on transfusion or try to separate the effect of transfusion versus anemia on in-hospital mortality. In addition, somewhat unexpectedly, Habib RH [1] also found that hemodilutional anemia on bypass was associated with long-term adverse effects as well. Ongoren MC [6] found that blood transfusion during or after cardiac operation is associated with an increased risk of death over the

Table 5 Effects of various variables on the transfusion requirement of packed red blood cell based on univariate and multivariate logistic regression analyses

\begin{tabular}{|c|c|c|c|c|c|c|}
\hline & \multicolumn{3}{|c|}{ Univariate } & \multicolumn{3}{|c|}{ Multivariate } \\
\hline & Unadjusted odds ratio & $95 \% \mathrm{Cl}$ & $p$ value & Adjusted* odds ratio & $95 \% \mathrm{Cl}$ & $\mathrm{p}$ value \\
\hline Age & 3.1 & $1.11-4.34$ & 0.034 & 2.3 & $1.67-3.53$ & 0.065 \\
\hline Female & 1.12 & $0.92-1.85$ & 0.004 & 3.91 & $2.99-3.81$ & 0.023 \\
\hline Diabetes & 1.23 & $0.95-2.88$ & 0.844 & & & \\
\hline $\mathrm{EF}$ & 0.86 & $0.59-1.96$ & 0.101 & & & \\
\hline CPB time & 2.33 & $1.99-3.10$ & 0.006 & 1.7 & $1.1-2.91$ & 0.001 \\
\hline$X$-clamp time $>60 \mathrm{~min}$ & 2.16 & $1.91-2.55$ & 0.003 & 4.45 & $3.94-4.98$ & 0.001 \\
\hline COPD & 4.61 & $1.13-7.29$ & 0.673 & & & \\
\hline LITA & 2.34 & $0.25-4.81$ & 0.123 & & & \\
\hline Radial artery & 2.45 & $1.31-4.02$ & 0.678 & & & \\
\hline $\mathrm{BSA}<1.60 \mathrm{~m}^{2}$ & 3.71 & $3.34-4.95$ & 0.001 & 3.83 & $3.67-5.13$ & $<0.001$ \\
\hline Crystalloid cardioplegia & 1.25 & $0.91-1.62$ & $<0.001$ & 0.78 & $0.18-1.2$ & $<0.001$ \\
\hline
\end{tabular}

*Adjusted for ejection fraction, cross-clamp time, LITA, COPD.

$E F$ ejection fraction, CPB cross-clamp time, LITA left internal thoracic artery, COPD chronic obstructive pulmonary disease, BSA body surface area. 
subsequent five years. He showed that transfused patients also had twice the 5 -year mortality ( $15 \%$ vs $7 \%$ ) of nontransfused patients. After correction for comorbidities and other factors, transfusion was still associated with a $70 \%$ increase in mortality. We did not find statistically significant difference for mortality between two groups. All these statistical studies emphasized the importance of blood saving both intra-operative and postoperative period. Many blood precaution techniques has been developed for reducing the risk of intra-operative hemodilution and blood transfusion [8,9]. Predisposing factor for intra-operative hemodilution and transfusion requirement has been described. Multivariate analyses has proved that previous anemia, female gender [13], low BSA, advanced age, СРB time, and renal failure as predictor of intraoperative hemodilution [2-9]. Hemodilution during CPB results from the mixing of pump crystalloid and colloid prime solution with the patient's blood, and these two relative volumes, along with pre- $\mathrm{CPB}$, will largely determine the nadir value. In addition to above mentioned variables, the type of cardioplegia also effects intraoperative hemodilution. There weren't any prospective randomized study, identified crystalloid cardioplegia as predictor of hemodilution and transfusion requirement. Eucher PM noticed the hemodilutive effect of crystalloid cardioplegia and described a technique to remove crystalloid cardioplegia by retrograde cardioplegia cannula [14]. We performed this prospective randomized study to identify cristalloid cardioplegia as the predictor of hemodilution. Our multivariate study proved that above mentioned variables (previous anemia, female gender, low BSA, advanced age, CPB time, and renal failure) as predictor of intra-operative hemodilution. But our multivariate analyses also proved that crystalloid cardioplegia is also predictor of intraoperative hemodilution $(\mathrm{p}<0.001$, $\mathrm{OR}=0.19$ ). Transfusion requirement predictors were also well proved. Our study proved that crystalloid cardioplegia is also strong predictor of transfusion requirement $(\mathrm{p}<0.001, \mathrm{OR}=0.78)$. The positive effects of blood cardioplegia are well known. We won't discuss this preventive ways of blood cardioplegia because of avoiding confounding information.

Another alternative method for applying cardioplegia is minicardioplegia. Its difference from blood cardioplegia consists in the fact that it is applied without diluting the blood in a ratio of $1 / 4$ or $1 / 8$. In the related literature it is possible to find various publications on this topic. In their study, Rıza Türköz et al. found that this method did not necessitate too much volume during pumping and prevented hemodilution from occurring at a high level, while it ensured safe protection of the myocardium [21]. It has been argued in another study that minicardioplegia is more advantageous as regards myocardial edema after ischemic damage [22]. In contrast to these findings, however, there also studies arguing that this method does not provide any advantages over standard blood cardioplegia [23].

\section{Conclusion}

Crystalloid cardioplegia, compared to blood cardioplegia not only causes much more intra-operative hemodilution but also increases the blood transfusion requirement. Hemodilution and increased transfusion increases the ICU and hospital stay, in the early postoperative period.

\section{Abbreviations}

CPB: Cardiopulmonary bypass; BSA: Body surface area; Htc: Hematocrit; RBC: Red blood cell; CABG: Coronary artery bypass graft; OR: Odds ratios; ICU: Intensive care unit.

\section{Competing interests}

The authors declare that they have no competing interests.

\section{Authors' contributions}

MG, MD = Author. HB, MD = Data collection, Author, Concept/design, Data analysis/interpretation, Critical revision of article, Approval of article. Both authors read and approved the final manuscript.

\section{Author details}

'Department of Cardiovascular Surgery, Baskent University Faculty of Medicine, Ankara, Turkey. ${ }^{2}$ Department of Cardiovascular Surgery, Ankara Çankaya Hospital, Aşağı Dikmen mah. 575 sok, Orankent konutları B blok No:12, OR-AN Çankaya, Ankara, Turkey.

Received: 29 September 2013 Accepted: 30 December 2013 Published: 27 January 2014

\section{References}

1. Habib RH, Zacharias A, Schwann TA, Riordan CJ, Durham SJ, Shah A: Adverse effects of low hematocrit during cardiopulmonary bypass in the adult: Should current practice be changed? I Thorac Cardiovasc Surg 2003, 125:1438-1450.

2. DeFoe GR, Ross CS, Olmstead EM, Surgenor SD, Fillinger MP, Groom RC, et al: Lowest hematocrit on bypass and adverse outcomes associated with coronary artery bypass grafting. northern new england cardiovascular disease study group. Ann Thorac Surg 2001, 71:769-776.

3. Schwann TA, Habib RH, Zacharias A, Parenteau GL, Riordan CJ, Durham SJ, et al: Effects of body size on operative, intermediate and long-term outcomes after coronary artery bypass operation. Ann Thorac Surg 2001, 71:521-531

4. Ranucci M, Pazzaglia A, Bianchini C, Bozzetti G, Isgrò G: Body size, gender, and transfusions as determinants of outcome after coronary operations. Ann Thorac Surg 2008, 85:481-487.

5. O'Connor GY, Plume SK, Olmstead EM, et al: Multivariate prediction of in-hospital mortality associated with coronary artery bypass surgery. The Northern New England Cardiovascular Disease Study Group. Circulation 1992, 85:2110-2118.

6. Engoren MC, Habib RH, Zacharias A, Schwann TA, Riordan CJ, Durham SJ: Effect of blood transfusion on long-term survival after cardiac operation. Ann Thorac Surg 2002, 74:1180-1186.

7. Silliman CC, Paterson AJ, Dickey WO, et al: The association of biologically active lipids with the development of transfusion- related acute lung injury: a retrospective study. Transfusion 1997, 37:719-726.

8. Swaminathan M, Phillips-Bute BG, Conlon PJ, Smith PK, Newman MF, Stafford-Smith M: The association of lowest hematocrit during cardiopulmonary bypass with acute renal injury after coronary artery bypass surgery. Ann Thorac Surg 2003, 76:784-792

9. The Society of Thoracic Surgeons Blood Conservation Guideline Task Force, Ferraris VA, Ferraris SP, Saha SP, Hessel EA II, Haan CK, Spiess BBD, Shore-Lesserson L, Stafford-Smith M, Brown CD, The Society of Cardiovascular Anesthesiologists Special Task Force on Blood David Royston, Bridges CR, Higgins RSD, Despotis G, Jeremiah R: Perioperative blood transfusion and blood 
conservation in cardiac surgery: the society of thoracic surgeons and the society of cardiovascular anesthesiologists clinical practice guideline. Ann Thorac Surg 2007, 83:27-86.

10. Buckberg GD: Oxygenated cardioplegia: blood is a many splendored thing. Ann Thorac Surg 1990, 50:175-177.

11. Louagie Y, Gonzalez E, Jamart J, Bulliard G, Schoevaerdts JC Postcardiopulmonary bypass lung edema. A preventable complication? Chest 1993, 103:86-95.

12. Calafiore AM, Teodori G, Mezzetti A, Bosco G, Verna AM, Di Giammarco G, Lapenna D: Intermitent antegrade warm blood cardioplegia. Ann Thorac Surg 1995, 59:398-402.

13. Pöling J, Rees W, Mantovani V, Klaus S, Bahlmann L, Ziaukas V, Hübner N, Warnecke $\mathrm{H}$ : Evaluation of myocardial metabolism with micordialysis during bypass surgery with cold blood - or Calafiore cardioplegia. Eu J Cardio-thoracic Surg 2006, 30:597-603.

14. Eucher PM, Buche M, Broka S, Schoevaerdts JC: Retrieval of crystalloid cardioplegic solutions. Ann Thorac Surg 1996, 61:746-747.

15. Guru V, Omura J, Alghamdi AA: Is blood superior to crystalloid cardioplegia? A meta-analysis of randomized clinical trials. Circulation 2006, 114(suppl I):-1-331-I-338.

16. Follette DM, Mulder DG, Maloney JV, Buckberg GD: Advantages of blood cardioplegia over continuous coronary perfusion or intermittent ischemia. Experimental and clinical study. J Thorac Cardiovasc Surg 1978, 76:604-619.

17. Buckberg GD: A proposed "solution" to the cardioplegic controversy. J Thorac Cardiovasc Surg 1979, 77:803-815.

18. Braimbridge MV, Chayen J, Bitensky L, Hearse DJ, Jynge P, Cankovic-Darracott S: Cold cardioplegia or continuous coronary perfusion? Report on preliminary clinical experience as assessed cytochemically. J Thorac Cardiovasc Surg 1977, 74:900-906.

19. Øvrum E, Tangen G, Tølløfsrud S, Øystese R, Ringdal MAL, Istad R: Cold blood cardioplegia versus cold crystalloid cardioplegia: a prospective randomized study of 1440 patients undergoing coronary artery bypass grafting. J ThoracCardiovascSurg 2004, 128:860-865.

20. Rinne T, Pehkonen E, Kaukinen S, Tarrka M: Comparison of cardioprotection with crystalloid and blood cardioplegia in CABG patients. J Cardiothorac Vasc Anesth 1993, 7:679-683.

21. Türköz R, Gülcan O, Türköz A: Cardioplegia by minicardioplegia technique. Anadolu Kardiyol Derg 2006, 6:178-179.

22. McCann UG 2nd, Lutz CJ, Picone AL, Searles B, Gatto LA, Dilip KA, Nieman GF: Whole blood cardioplegia (minicardioplegia) reduces myocardial edema after ischemic injury and cardiopulmonary bypass. J Extra Corpor Technol 2006, 38:14-21. abstract.

23. Kirali K: Which application, complex or mini cardioplegia?/Cardioplegia by minicardioplegia technique. Anadolu Kardiyol Derg 2006, 6:289-290.

doi:10.1186/1749-8090-9-23

Cite this article as: Günday and Bingöl: Is crystalloid cardioplegia a strong predictor of intra-operative hemodilution? Journal of Cardiothoracic Surgery 2014 9:23.

\section{Submit your next manuscript to BioMed Central and take full advantage of:}

- Convenient online submission

- Thorough peer review

- No space constraints or color figure charges

- Immediate publication on acceptance

- Inclusion in PubMed, CAS, Scopus and Google Scholar

- Research which is freely available for redistribution 